\title{
THE GROUND-WATER RESOURCES IN THE ROSS BARNETT RESERVOIR AREA, MISSISSIPPI
}

\author{
by \\ W. T. Oakley \\ Hydrologic Technician \\ U.S. Geological Survey
}

U. S. GEOLOGICAL SURVEY
Water-Resources Investigations Report $84-4160$

Prepared in cooperation with the

PEARL RIVER VALLEY WATER SUPPLY DISTRICT

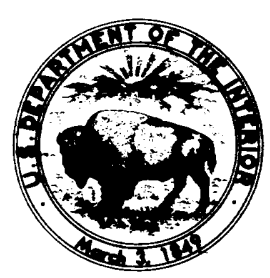

Jackson, Mississippi 


\title{
UNITED STATES DEPARTMENT OF THE INTERIOR
}

\author{
WILLIAM P. CLARK, SECRETARY
}

\section{GEOLOGICAL SURVEY}

\author{
Dallas L. Pock, Director
}

For additional information write to:

\section{District Chief}

U.S. Geologlcal survey

Water Resources Division

100 West Capltal Street, Sulte 710

Jackson, Mississippl 39269

Tetephone: (601) 960-4600
Coples of this report can be purchased from:

Open-File Services Section

Western Distrlbution Branch

U.S. Geologlcal Survey

Box 25425. Federal Center Lakewood, Colorado 80225

Telephone: (303) 234-5888 


\section{CONTENTS}

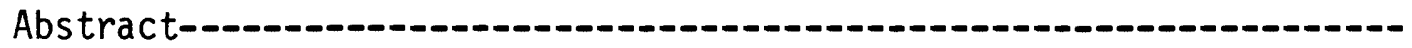

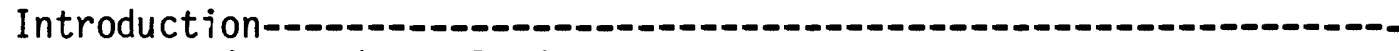

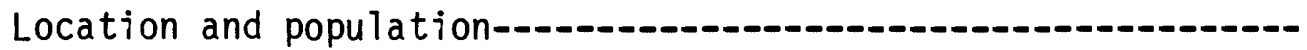

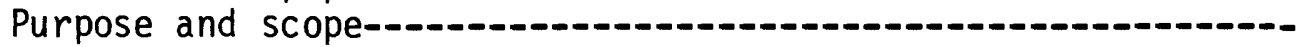

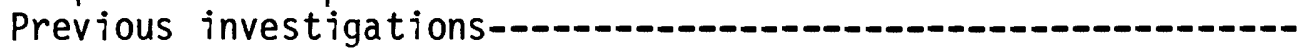

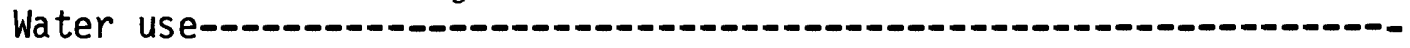

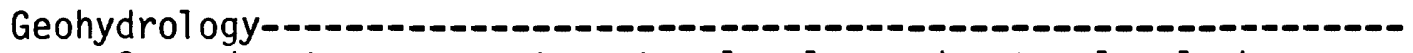

Ground-water movement, water levels, and water-level changes--

Ground-water qual ity----------

Potential for future ground-water supply development--.-.--.--.---.-

Summary and conclusions--.--.--

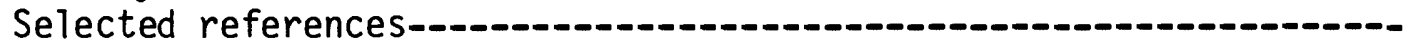

\section{ILLUSTRATIONS}

Figure 1. Map showing geology of Jackson metropolitan area, location of study area, and location of geohydrologic section A-A'-_-

2. Map showing locations of water wells in the Ross Barnett Reservoir area-......

3. Geohydrologic section A-A' from Warren to Scott County---

4. Map showing configuration of the top of the Sparta Sand-1--_-

5. Map showing configuration of the top of the Cockfield Formation--.-.-

6. Map showing configuration of the top of the Meridian-upper Wilcox aquifer--

7. Geohydrologic section B-B' through the Ross Barnett Reservoir area-.....-...-

8. Water-level hydrographs from observation wells in and near the Ross Barnett Reservoir area-...-..-

9. Potentiometric surface of the Cockfield aquifer in the Ross Barnett Reservoir area, 1983-...-..-

10. Potentiometric surface of the Sparta aouifer in the

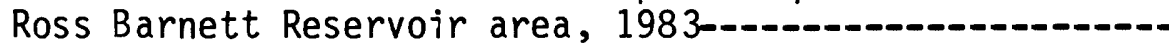

11. Water-level hydrograph of well W5 and ground-water withdrawal from the Cockfield aquifer in the Ross Barnett Reservoir area-_.

12. Map showing concentration of iron in ground water in

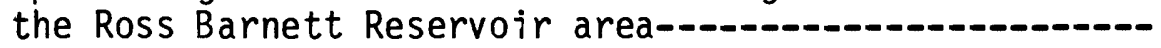

13. Map showing variations in color in ground water in the Ross Barnett Reservoir area--.--

14. Water-quality changes along geohydrologic section B-B'-- 


\section{TABLES}

Table 1. Data for water wells in the Ross Barnett Reservoir area---------.-- 4

2. Geologic units and their water-bearing properties in the Ross Barnett Reservoir area-.......-...- 8

3. History of water-level changes in the Ross Barnett Reservoir area-.-...-..- 20

4. Results of chemical analyses of water from selected wells in the Ross Barnett Reservoir area-...........- 23

\section{FACTORS FOR CONVERTING INCH-POUND UNITS TO INTERNATIONAL SYSTEM (SI) UNITS}

Multiply

inch (in.)

foot $(\mathrm{ft})$

mile (mi)

acre

square mile $\left(m i^{2}\right)$

gallons per minute (gal/min)

million gallons per day

cubic foot $\left(\mathrm{ft}^{3}\right)$

feet per mile $(\mathrm{ft} / \mathrm{mi})$

cubic feet per day per square

foot $\left(\mathrm{ft}^{3} / \mathrm{d}\right) / \mathrm{ft}^{2}$ or $\mathrm{ft} / \mathrm{d}$

cubic feet per day per foot

$\left(\mathrm{ft}^{3} / \mathrm{d}\right) / \mathrm{ft}$ or $\mathrm{ft}^{2} / \mathrm{d}$

gallons per minute per foot

of drawdown (gal/min)/ft

By
25.4
.3048
1.609
4047
2.590
.06309
$6.309 \times 10^{-5}$
3,785
.02832
18.9
.189
.3048
.0929
.21

To obtain

millimeters (mm)

meter ( $\mathrm{m}$ )

kilometers $(\mathrm{km})$

square meter

square kilometer $\left(\mathrm{km}^{2}\right)$

liters per second $(L / S)$

cubic meters per second $\left(\mathrm{m}^{3} / \mathrm{s}\right)$

cubic meters per day $\left(\mathrm{m}^{3} / \mathrm{d}\right)$

cubic meter $\left(\mathrm{m}^{3}\right)$

centimeters per kilometer $(\mathrm{cm} / \mathrm{km})$

meters per kilometer $(\mathrm{m} / \mathrm{km})$

cubic meters per day per square meter $\left(\mathrm{m}^{3} / \mathrm{d}\right) \mathrm{m}^{2}$ cubic meters per day $\left(\mathrm{m}^{3} / \mathrm{d}\right) / \mathrm{m}$

liters per second per meter $(\mathrm{L} / \mathrm{s}) / \mathrm{m}$

The conversion from temperature in degrees Fahrenheit ( $\left.{ }^{\circ} \mathrm{F}\right)$ to temperature in degrees Celsius $\left({ }^{\circ} \mathrm{C}\right)$ is expressed by: ${ }^{\circ} \mathrm{C}=5 / 9\left({ }^{\circ} \mathrm{F}-32\right)$.

National Geodetic Vertical Datum of 1929 (NGVD of 1929): A geodetic datum derived from a general adjustment of the first-order level nets of both the United States and Canada, formerly called Mean Sea Level Datum of 1929; referred to as sea level in this report. 


\title{
THE GROUND-WATER RESOURCES IN THE ROSS BARNETT RESERVOIR AREA, MISSISSIPPI
}

By

\author{
W. T. Oakley
}

\begin{abstract}
The Ross Barnett Reservoir area occupies an area of about 78 square miles of a 490 square mile study area northeast of the City of Jackson. For several years water use in the area has increased and during 1983 about 0.57 million gallons per day were obtained from ground-water sources. Virtually all ground water in the area is used for public supplies.

The principal aquifers currently used in the area are in the Sparta Sand and the Cockfield Formation. The Sparta Sand is the most intensively developed and generally the highest yielding aquifer in the study area. Water-level declines have averaged 2 to 3 feet per year since 1940.

The principal source of ground-water recharge to the aquifers is precipitation on outcrops of permeable strata northeast of the area. The base of freshwater is at the base of the Meridian-upper Wilcox aquifer except in the extreme northeast part of the area where the lower Wilcox aquifer contains freshwater. Water from the aquifers is suitable for public-supply use without treatment except in a few places where iron concentrations are high. Iron concentrations ranged from 0.10 to 9.3 milligrams per liter. Excessive color is a problem in the water from some wells in the area. Color was 20 units or greater in 8 of 25 wells sampled.
\end{abstract}

\section{INTRODUCTION Location and Population}

The Jackson, Mississippi metropolitan area includes Hinds, Madison, and Rankin Counties in southwest-central Mississippi. The metropolitan area encompasses the most populous and industrialized area of the State. The study area northeast of Jackson comprises about $490 \mathrm{mi}^{2}$ and includes the Ross Barnett Reservoir. The reservoir lake consists of about $50 \mathrm{mi}^{2}$, or 32,000 acres, and extends upstream from the spillway into Leake County (fig. 1). The area in the vicinity of Ross Barnett Reservoir, during the past 20 years, has been the fastest growing recreational and residential area in Mississippi. About 5,000 people reside in the study area. 


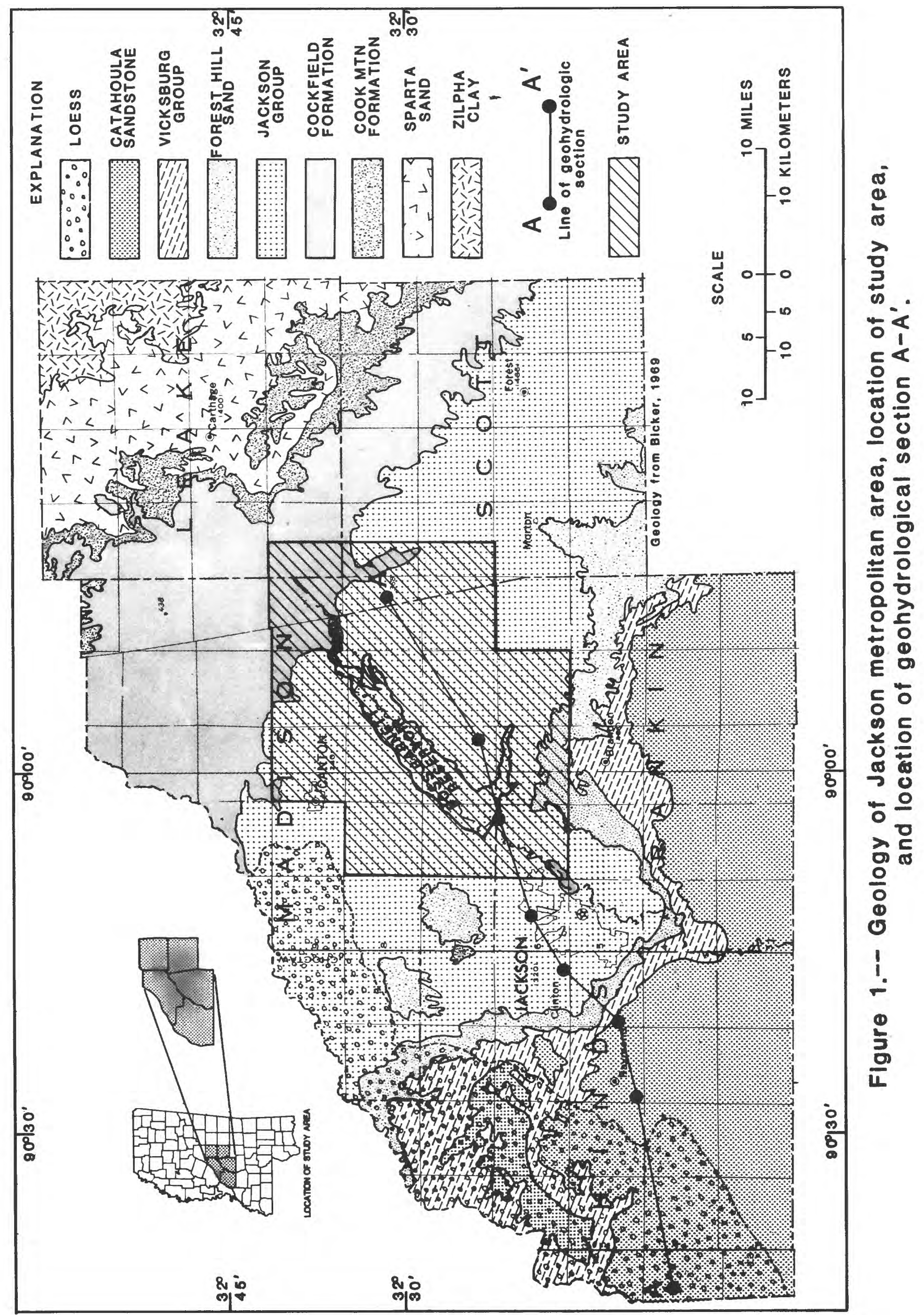




\section{Purpose and Scope}

The objectives of this study were to describe the depth and thickness of the principal water-bearing units and to define the variations in water quality and the utilization of ground water in the study area. Water quality, water levels, water use, and pumping data for wells in the area were collected and analyzed. Geophysical log data and water well logs were used to map the extent and thickness of the aquifers, and water-level measurements were used to construct potentiometric maps. Descriptions of water quality in the aquifers was defined by chemical analyses of water collected from wells in and near the study area.

This study of the ground-water resources of the Ross Barnett Reservoir area was made by the U.S. Geological Survey in cooperation with the Pearl River Valley Water Supply District.

\section{Previous Investigations}

Previous studies that include the reservoir area were conducted by the U.S. Geological Survey (Harvey and others, 1961; Spiers and Dalsin, 1979) and by the Mississippi Department of Natural Resources, Bureau of Geology (Priddy, 1960; Moore and others, 1965; Baughman and others, 1971). A series of hydrologic atlases prepared by the U.S. Geological Survey in cooperation with the Mississippi Department of Natural Resources, Bureau of Land and Water Resources, describe the various aquifers (Boswel1, 1976a, 1976b; Spiers, 1977a, 1977b; Newcome, 1976) and delineate water levels (Wasson, 1980a, 1980b, 1980c, 1981).

\section{WATER USE}

Most of the ground water used in the Ross Barnett Reservoir area of about $78 \mathrm{mi}^{2}$ is for public supplies. Domestic water use, insignificant before 1965, has increased to about $0.57 \mathrm{Mgal} / \mathrm{d}$ in 1983 . Most of the water is supplied by the Pearl River Valley Water Supply District system from wells that tap the Cockfield and Sparta aquifers. Virtually all ground water used in the study area before 1983 was pumped from the Cockfield aquifer; however, most of the ground water used in the Jackson metropolitan area is produced from the Sparta aquifer.

Other public water-supply systems proximate to the reservoir that use ground water from the Sparta Sand and the Cockfield Formation are the municipalities of Canton, Madison, Ridgeland, Castlewood Subdivision, and the Fannin, Langford, and Noramco Water Associations. The City of Jackson uses wells screened in the Sparta Sand and the Cockfield Formation as a source of public water supply in some areas. About $2 \mathrm{Mgal} / \mathrm{d}$ is pumped from the two aquifer systems by industries in the metropolitan area. Table 1 lists data for selected water wells owned by Pearl River Valley Water Supply District and by nearby water systems. Locations of the wells in the reservoir area are shown in figure 2. 


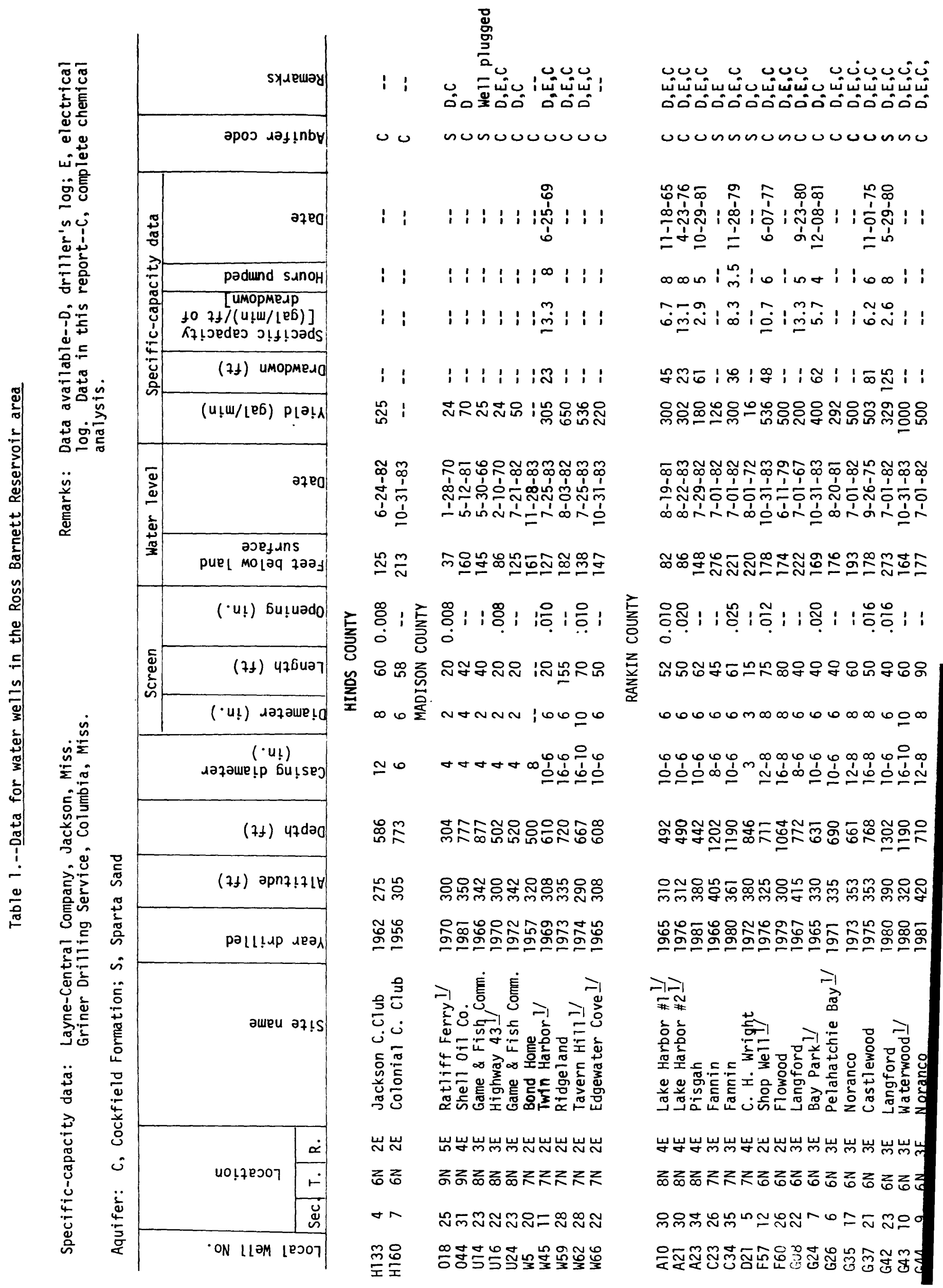




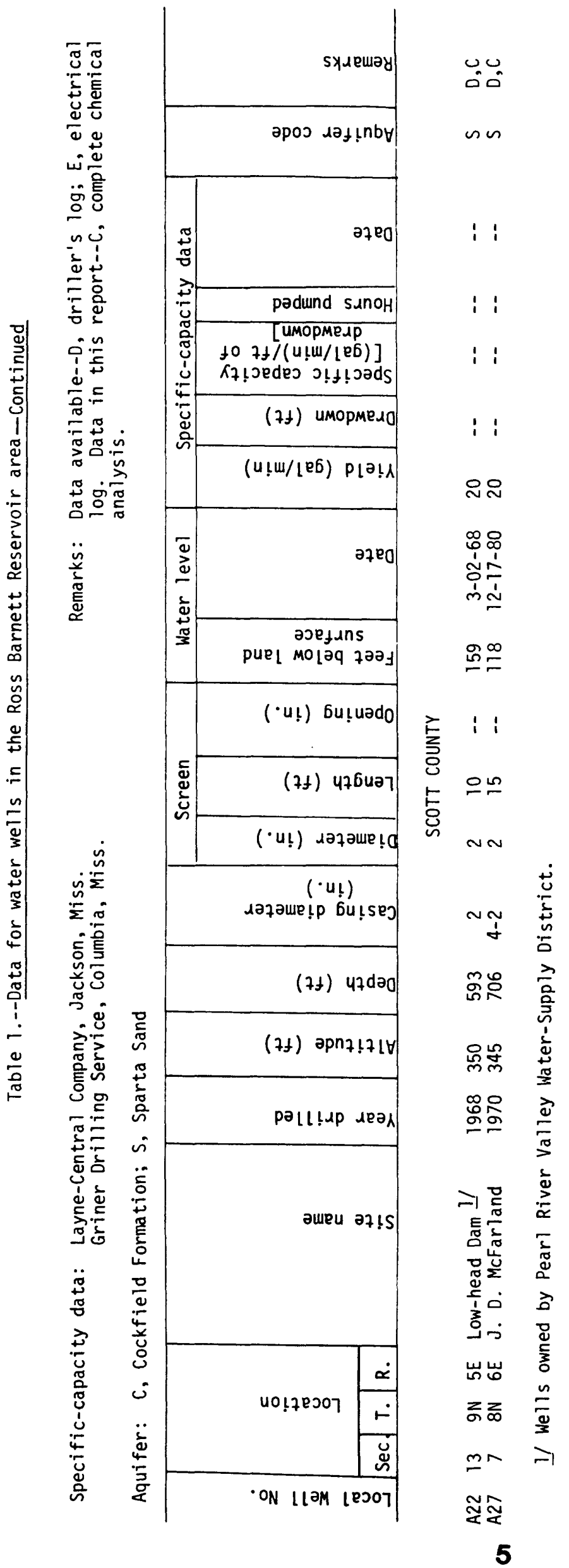




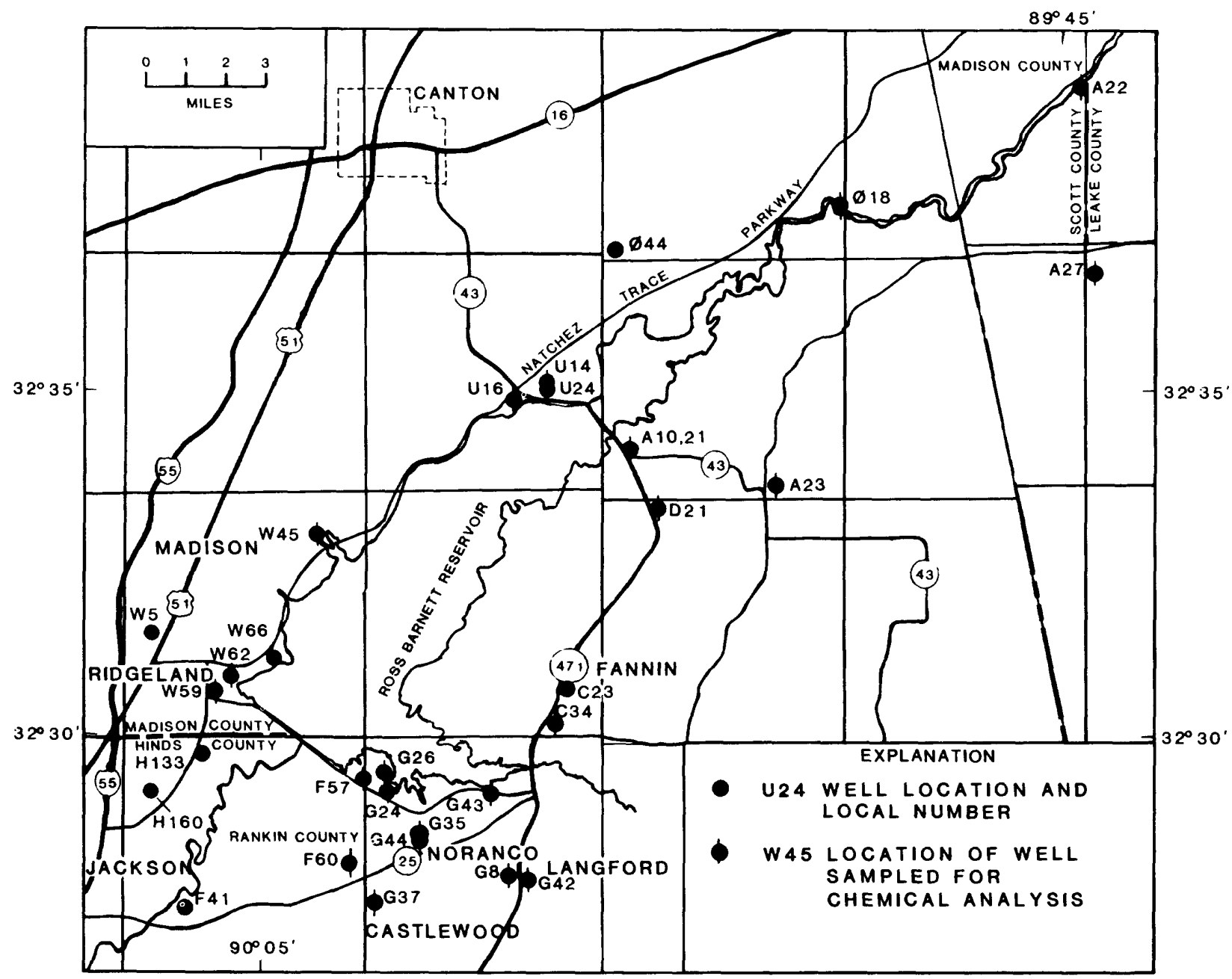

Figure 2.-- Location of water wells in the Ross Barnett Reservoir area. 


\section{GEOHYDROLOGY}

The Jackson metropolitan area, including the study area, lies within the south-central part of the Mississippi embayment of the Gulf Coastal Plain. The geologic units are of Tertiary to Quaternary age. The oldest outcropping strata in the area belong to the Zilpha Clay and the youngest deposits are Quaternary alluvium (fig. 1). The oldest and deepest freshwater-bearing strata in the subsurface is in the Wilcox Group and the youngest and shallowest significant aquifer is in the Cockfield Formation, both of Tertiary age. The principal ground-water sources available for use throughout most of the metropolitan area are aquifers in the Sparta Sand and Cockfield Formation (fig. 1). The principal source of water to the aquifers in the study area is precipitation on the outcrops of the permeable strata that form the aquifers of the area. The stratigraphic sequence, physical character, and water-bearing characteristics of the aquifers in the reservoir area are described in table 2.

The Tertiary strata in the region dip southwestward about 30 feet per mile. The regional dip is interrupted by the Jackson dome, where the strata are arched upward several hundred feet (fig. 3) and the outcrops of the Tertiary formations exhibit a concentric pattern (fig. 1). The dome affected deposition, thereby causing extreme variation in the water-bearing character of the aquifers, and is also related to higher than normal geothermal gradients.

The Sparta Sand is in the subsurface throughout the Jackson metropolitan area. The formation is about 300 feet thick in northern Madison County. An increase in thickness to about 500 feet occurs as the formation dips toward the Jackson dome from the northeast. The formation thins to less than 400 feet on the crest of the dome and thickens aga in to the southwest of the dome (fig. 3). The top of the formation decends from above sea level in northeastern Madison County to more than 500 feet below sea level in the southwestern part of the study area (fig. 4).

The Sparta consists of alternating beds of sand and clay. Lignite occurs either as grains disseminated in the strata or in beds as thick as several feet. The sand ranges from fine to medium grained. Some logs show as many as five distinct sand units in the sparta in the vicinity of the Jackson dome, and units vary in thickness from place to place. Structural conditions and variations in deposition cause pronounced differences in depth to the base of the formation in short distances.

The Cockfield Formation is at the surface or in the subsurface throughout the Jackson metropolitan area except in small localities in the extreme northeastern part of Madison County (fig. 1). Northern Madison County extends into the outcrop area; there is a small outcrop in the Jackson area where the strata have been uplifted. 


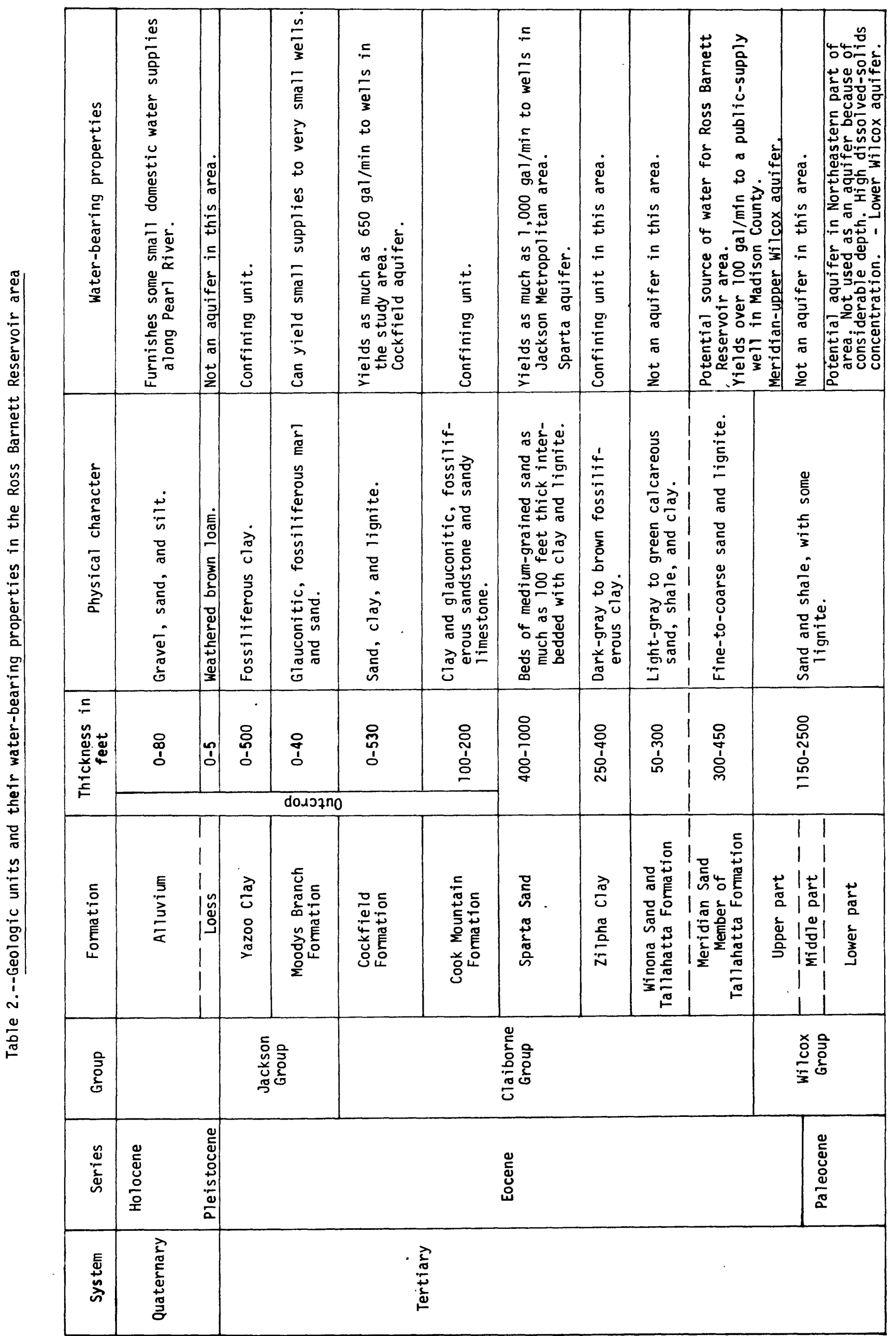




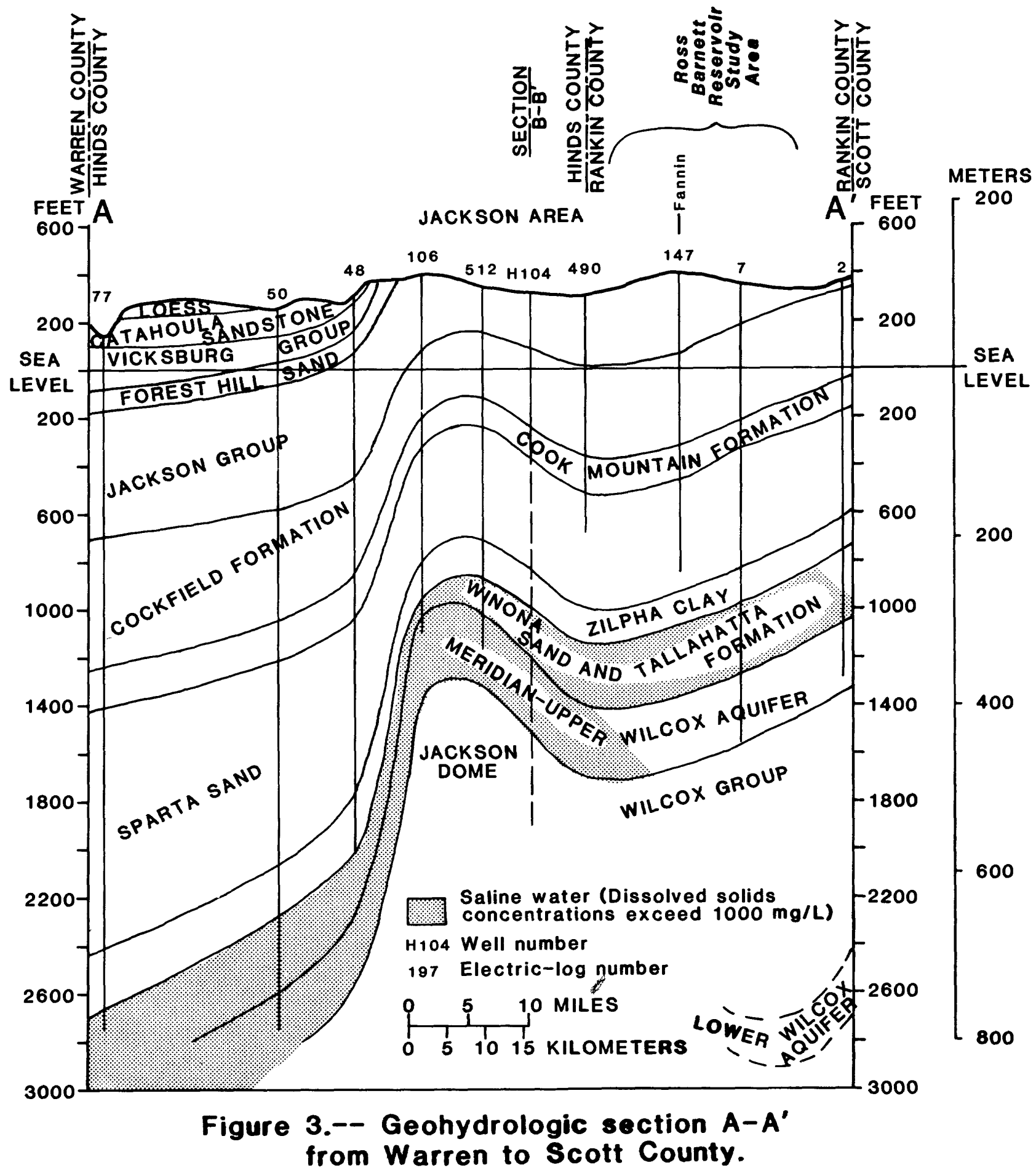




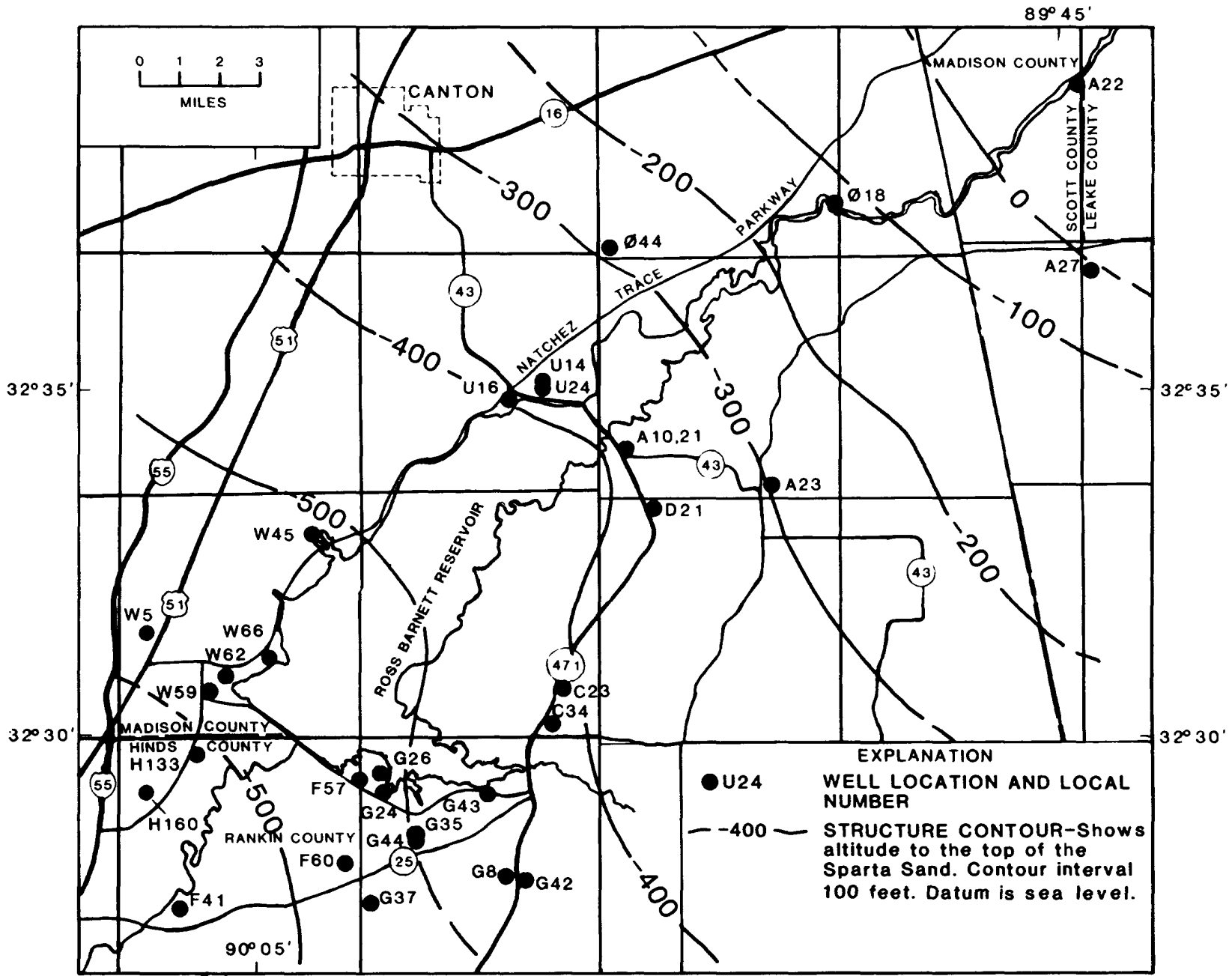

Figure 4.-- Configuration of the top of the Sparta Sand (modified from Harvey and others, 1964). 
The Cockfield Formation generally is between 300 and 400 feet thick. The minimum thickness known is 185 feet on the Jackson dome. In the syncline that borders the dome on the northeast, the cockfield is 100 to 150 feet thicker than on top of the dome (fig. 3).

The top of the Cockfield Formation crops out at an elevation of 360 feet in north-central Madison County and descends to a depth slightly below sea level in the southwestern part of the study area (fig. 5). The Cockfield Formation consists of sand, shale, and lignite. Lignite is common in many of the shale and clay beds and also as fragments or as thin beds in the sand. The water-bearing beds consist of fine-grained, micaceous sand. Generally the sand beds that form the Cockfield aquifers are composed of finer sand in thinner beds than occurs in the Sparta Sand.

The outcrop of the oldest freshwater aquifer, the lower Wilcox, is a northwest-southeast trending belt about 90 miles northeast of Jackson; however, this aquifer contains freshwater only in extreme northeastern Madison and Rankin Counties. The overlying Meridian-upper Wilcox aquifer, which crops out 60 to 70 miles northeast of Jackson, contains freshwater generally northeast of the Jackson dome, including most of the reservoir area. In the study area the Meridian-upper Wilcox is from 1,000 to 1,400 feet below sea level (fig. 6).

The altitudes of the tops of the three major geologic units in which the aquifers in the reservoir area occur are shown in figures 4-6. The location of major wells in the area with respect to position within the aquifers and to other wells is shown in figure 7.

\section{Ground-Water Movement, Water Levels, and Water-Level Changes}

Ground-water movement in the study area is southwestward in the Cockfield and Sparta aquifers. The direction and rate of movement is strongly influenced by cones of depression centered around the City of Jackson, where water levels have declined 2 to 3 feet per year since about 1940. Water-level declines in the Ross Barnett Reservoir area have been less pronounced (fig. 8). Figures 9 and 10 are potentiometric maps that show water levels in the cockfield and Sparta aquifers in 1983. A summary of water-level changes in wells in the reservoir area is given in table 3 .

Water levels in the Cockfield aquifer range from about 280 feet above sea level at the Leake County line to about 160 feet above sea level at the reservoir dam. The relation between withdrawals of ground water from the Cockfield aquifer and the water-level decline in the aquifer is shown in figure 11. In the same areas, water levels in the Sparta aquifer range from 200 feet above sea level to about 100 feet above. The lower water levels in the Sparta reflect the much larger 


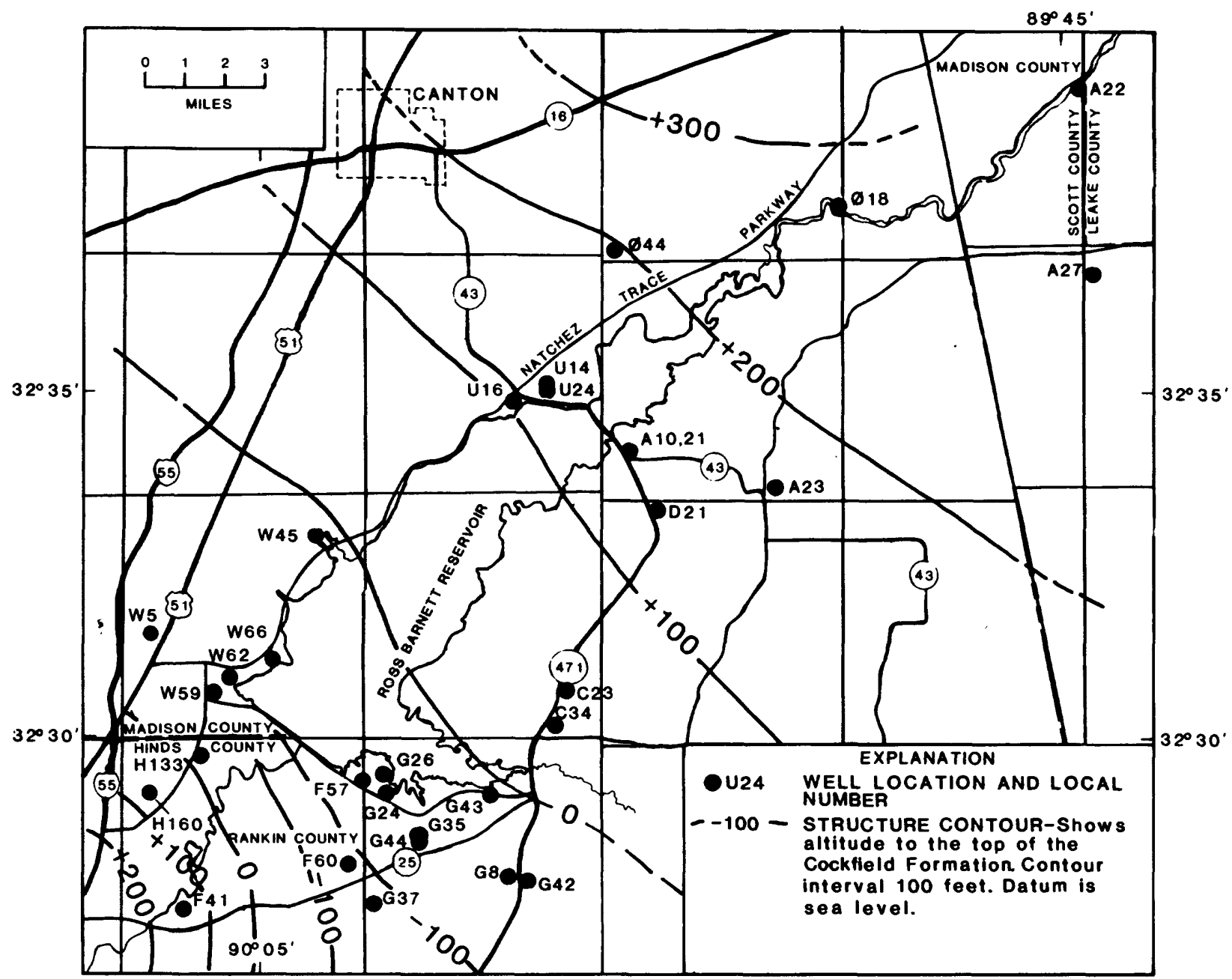

Figure 5.-- Configuration of the top of the Cockfield Formation (modified from Harvey and others, 1964). 


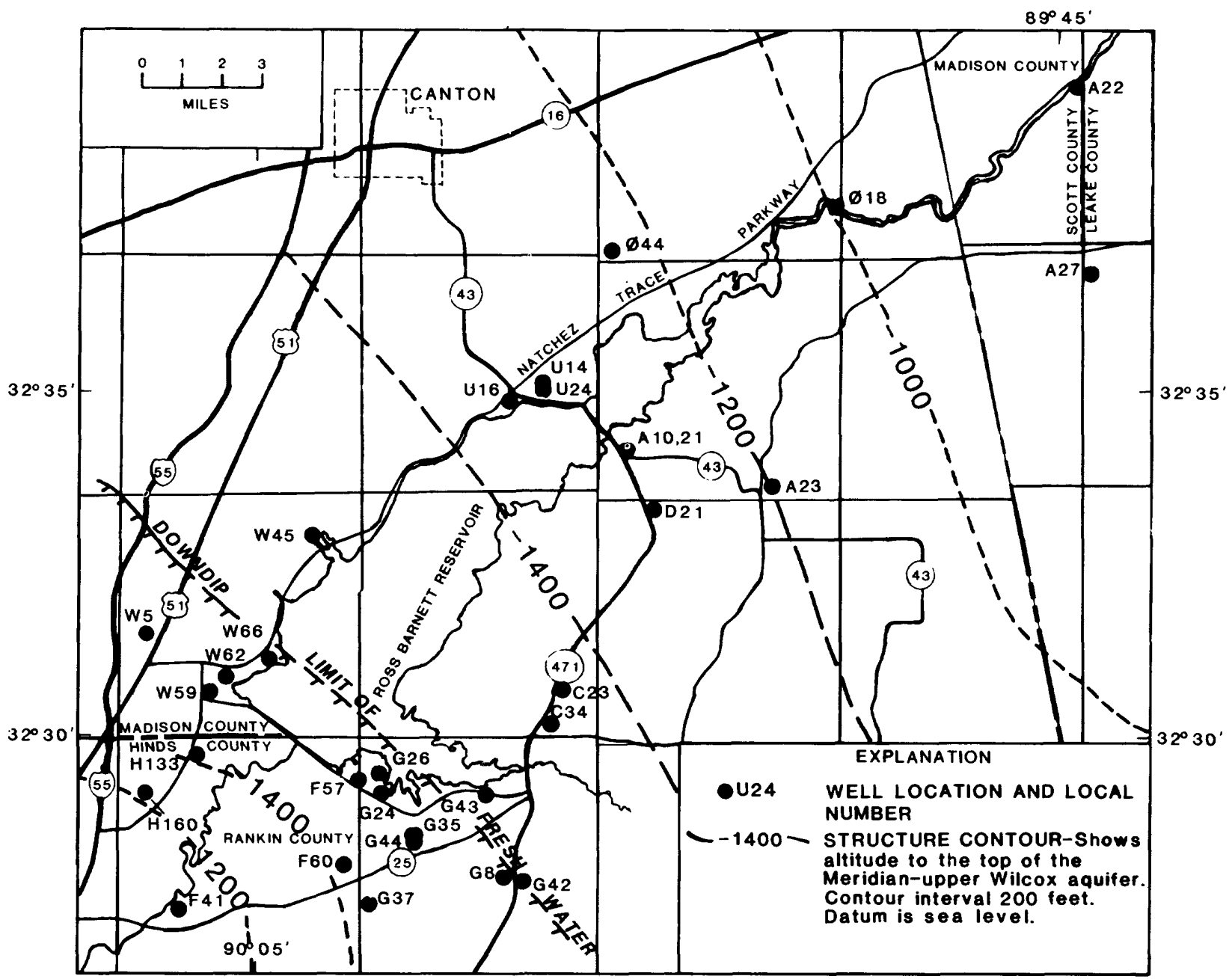

Figure 6.-- Configuration of the top of the Meridian-upper Wilcox aquifer (modified from Harvey and others, 1964). 

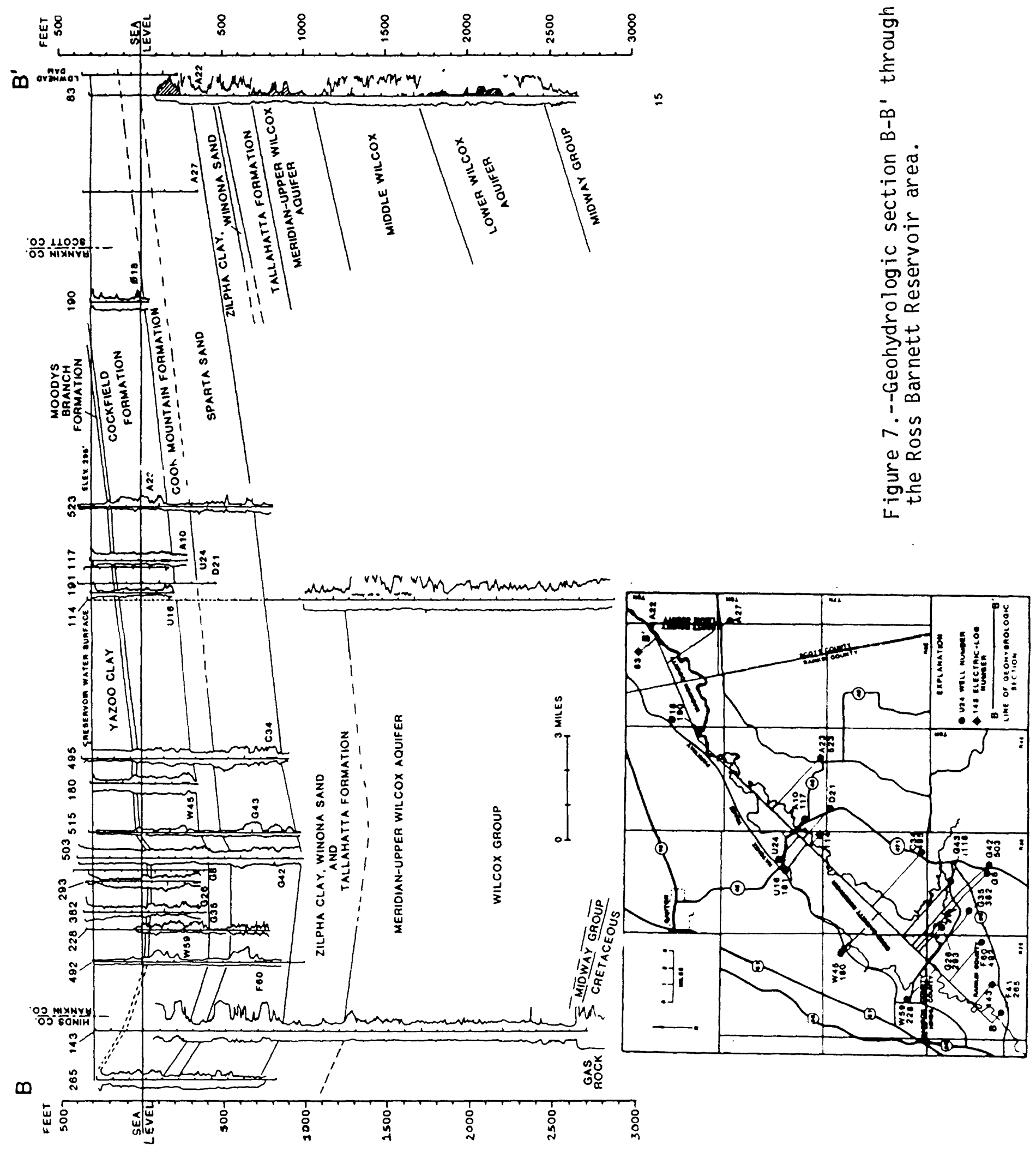

15 (page 17 fallows) 

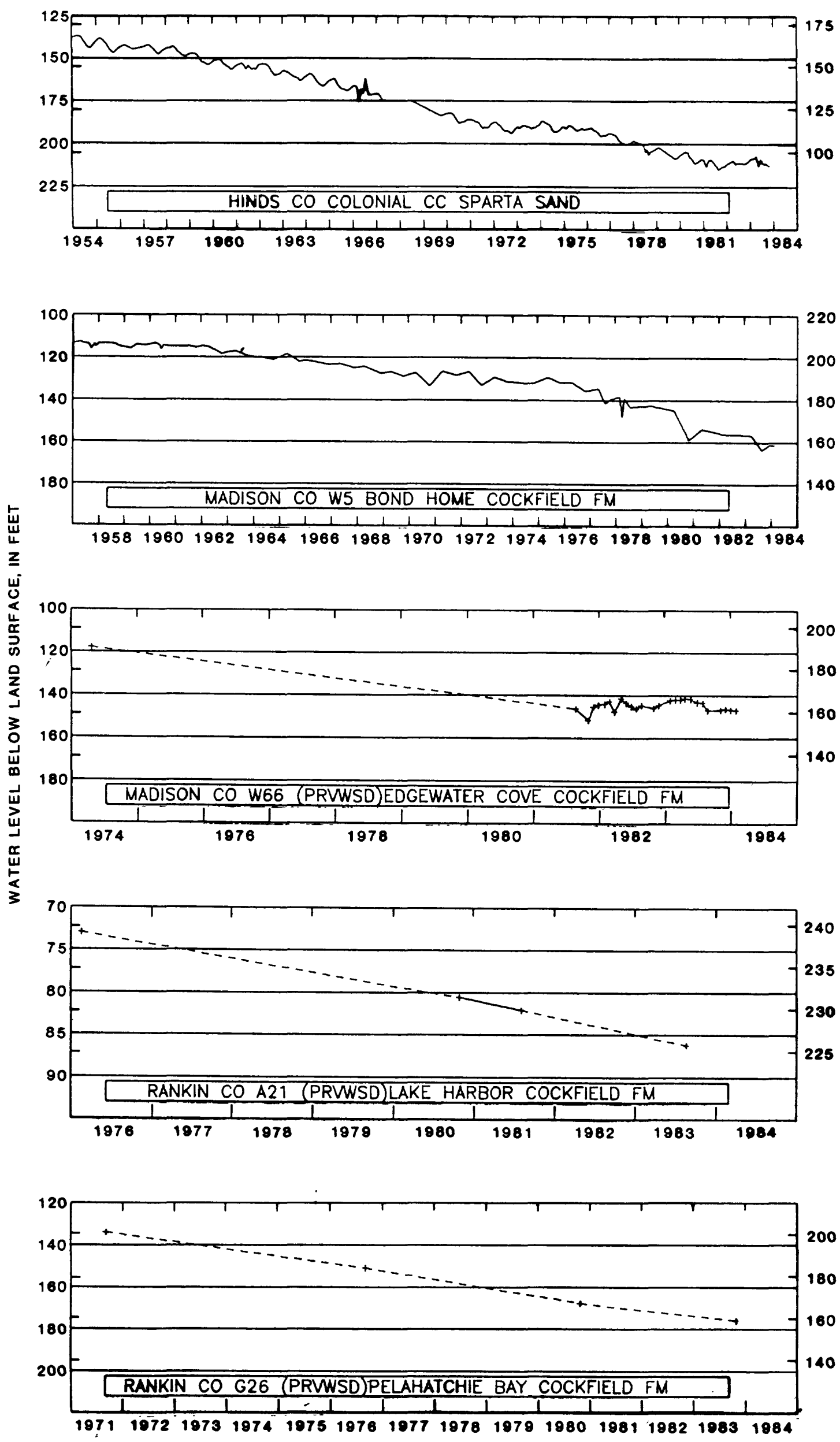

Figure 8.-- Water-level hydrographs from observation wells in and near the Ross Barnott Reservoir area. 


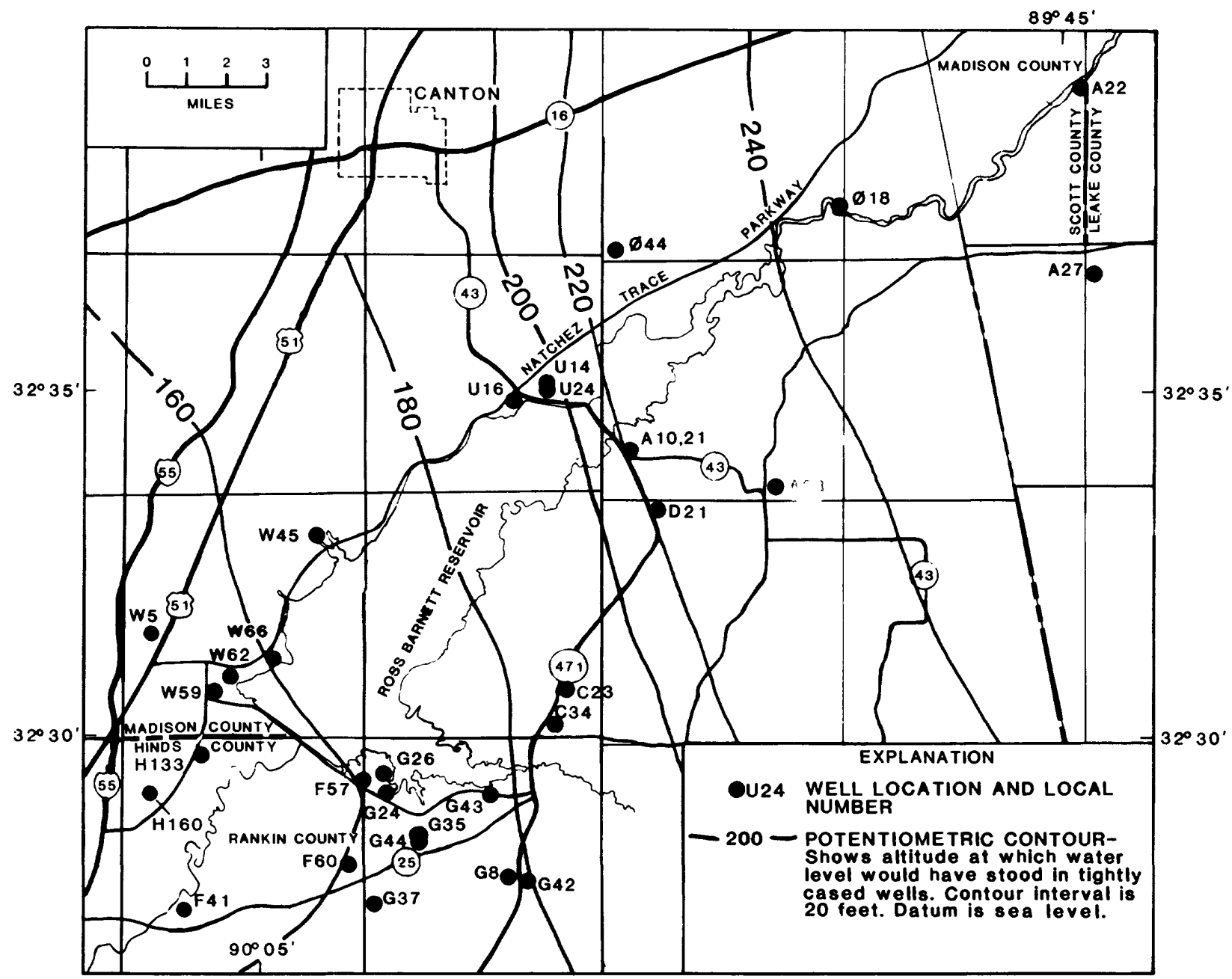

Figure 9.-- Potentiometric surface of the Cockfield aquifer in the Ross Barnett Reservoir area, 1983. 


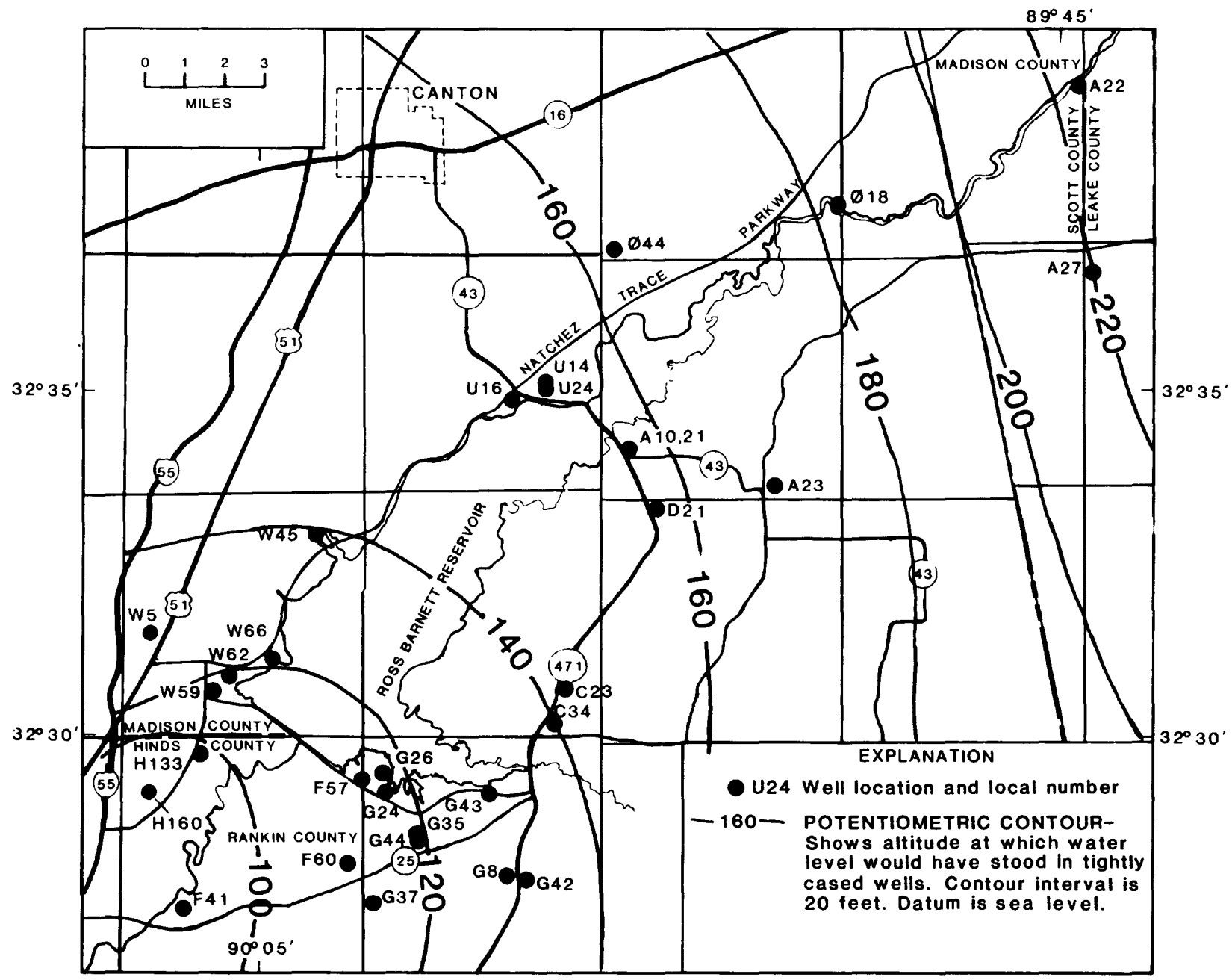

Figure 10.-- Potentiometric surface of the Sparta aquifer in the Ross Barnett Reservoir area, 1983. 
Table 3.--History of water-level changes in wells in the

Ross Barnett Reservoir area

\begin{tabular}{|c|c|c|c|c|c|c|}
\hline \multirow[t]{2}{*}{ Site name } & \multirow{2}{*}{$\begin{array}{c}\text { Local } \\
\text { wel1 } \\
\text { number }\end{array}$} & \multirow{2}{*}{$\begin{array}{r}\text { Wel1 } \\
\text { depth } \\
(\mathrm{ft})\end{array}$} & \multirow[t]{2}{*}{ Aquifer } & \multicolumn{3}{|c|}{$\begin{array}{l}\text { Water level below land surface } \\
\text { datum }(\mathrm{ft})\end{array}$} \\
\hline & & & & $\begin{array}{l}\text { Earliest } \\
\text { measurement }\end{array}$ & $1980-81$ & 1983 \\
\hline \multicolumn{7}{|c|}{ MADISON COUNTY } \\
\hline Twin Harbor & W45 & 610 & Cockfield & $98(1969)$ & 127 & 127 \\
\hline Tavern Hill & W62 & 667 & Cockfield & $110(1974)$ & 139 & 138 \\
\hline Edgewater Cove & W66 & 608 & Cockfield & $118(1974)$ & 146 & 147 \\
\hline \multicolumn{7}{|c|}{ RANKIN COUNTY } \\
\hline Lake Harbor \#1 & A10 & 492 & Cockfield & $70(1965)$ & 82 & 85 \\
\hline Lake Harbor \#2 & A22 & 490 & Cockfield & $73(1976)$ & 82 & 86 \\
\hline Shop Well & F57 & 711 & Cockfield & $134(1977)$ & 167 & 178 \\
\hline Bay Park & G24 & 631 & Cockfield & $120(1965)$ & 170 & 167 \\
\hline Pelahatchie Bay & G26 & 690 & Cockfield & $134(1971)$ & 176 & 169 \\
\hline Waterwood & G43 & 1190 & Sparta & $159(1980)$ & 165 & 164 \\
\hline
\end{tabular}




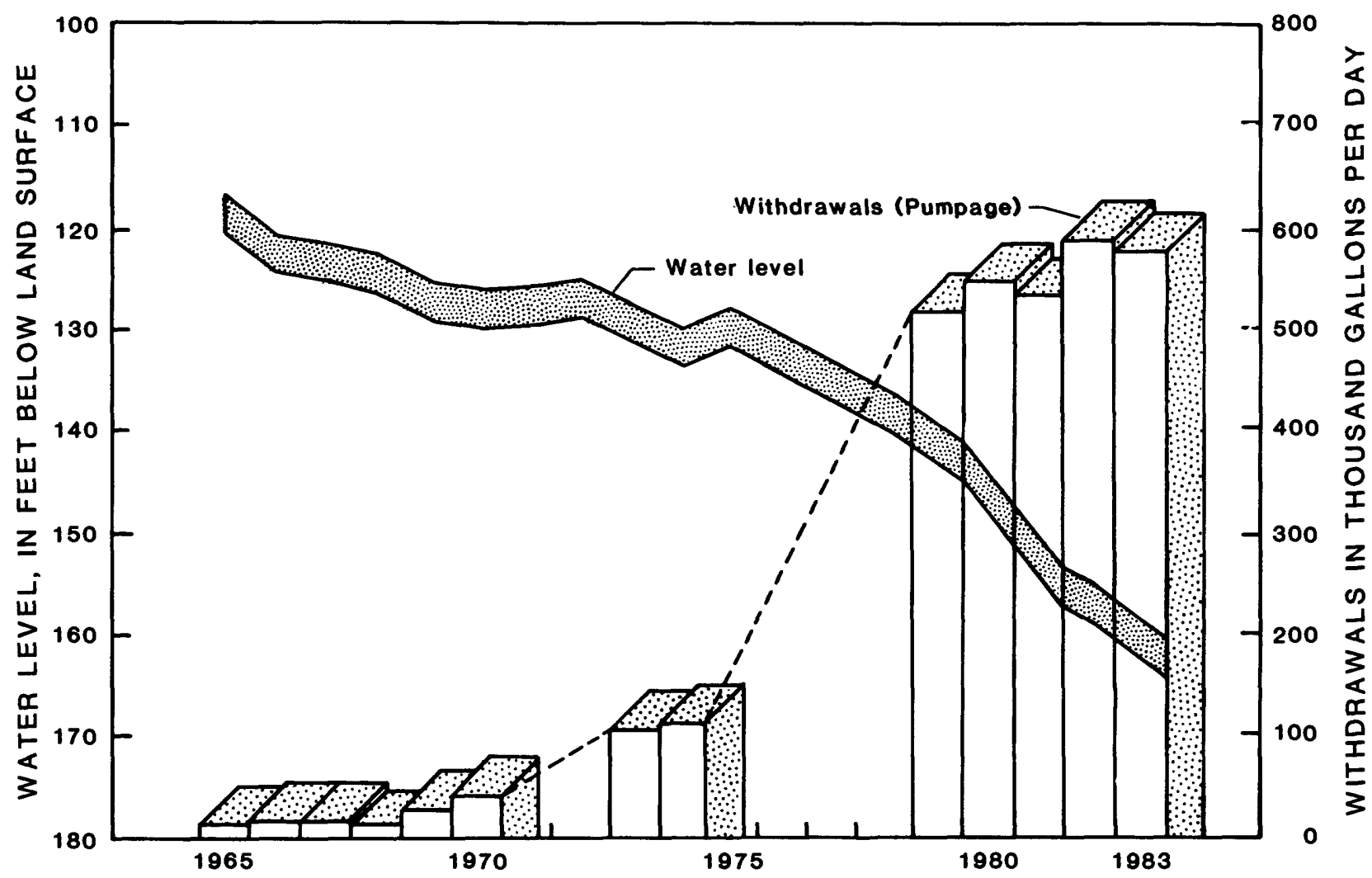

Figure 11.-- Water-level hydrograph of well W5 and ground-water withdrawal from the Cockfield aquifer in the Ross Barnett Reservoir area. 
withdrawals from the Sparta in the Jackson metropolitan area and lower predevelopment water levels. The water level in the Meridian-upper wilcox aquifer is about 270 feet above sea level -- very near land surface at low altitudes along the lake. Several wells located in the Pearl River flood plain at Jackson and screened in the Meridian-upper Wilcox aquifer flow slightly at altitudes of about 270 feet above sea level.

\section{Ground-Water Quality}

A summary of the chemical quality of ground water from water wells in the Ross Barnett Reservoir is given in table 4 . The most pronounced quality variation in the area is in iron in the Cockfield aquifer. Iron concentrations in the Cockfield aquifer increase with distance downdip from the recharge area until the vicinity of the Jackson dome is reached. Then the iron concentrations in both the Cockfield and Sparta decreases. The variations in iron concentration in the Cockfield and Sparta aquifers are shown in figure 12. Manganese concentrations generally are higher in areas where there are high iron concentrations. In general, the pattern of distribution of manganese follows that of iron. Iron concentrations exceed $0.30 \mathrm{mg} / \mathrm{L}$ (milligrams per liter) in 11 of 23 water samples from 21 wells and manganese concentrations exceed $0.05 \mathrm{mg} / \mathrm{L}$ in 11 of 25 water samples from 22 wells. The cited concentrations of both constituents exceed the limits for drinking water in either natural or treated water as established by the U.S. Environmental Protection Agency (1976).

Water in the study area is generally soft (1ess than $60 \mathrm{mg} / \mathrm{L}$ as $\mathrm{CaCO}_{3}$ ) in 19 of 23 wells sampled. The $\mathrm{pH}$ ranges from 6.5 to 8.5 units. Dissolved-solids concentration in all wells sampled is less than $500 \mathrm{mg} / \mathrm{L}$. The dissolved-solids concentration in both aquifers increases from northeast to southwest, but only the lower wilcox and Meridian-upper Wilcox aquifers become slightly saline (greater than $1,000 \mathrm{mg} / \mathrm{L}$ as determined from geophysical logs) in the Ross Barnett Reservoir area. Sodium increases, hardness decreases, and water becomes a sodium-bicarbonate type as aquifers deepen downdip.

Measured temperatures in the aquifers range from $68.0^{\circ}$ to $89.0^{\circ} \mathrm{F}$ $\left(20.0^{\circ}\right.$ to $\left.31.0^{\circ} \mathrm{C}\right)$ in wells that range in depth from about 300 feet to about 1,300 feet. Temperature of ground water in the southwestern part of the study area increases about $2.1^{\circ} \mathrm{F}$ per 100 feet below depths greater than 300 feet. The geothermal gradient is higher near the Jackson dome (see well Rankin F60).

Intensity of color in water in the Cockfield and Sparta aquifers is thought to be related to concentration and type of organic material that was deposited in the aquifers. Color was 20 units or greater in 8 of 25 samples. Limited data show little discernable correlation of color within the two aquifer systems in use; however, color may be more revalent in the basal strata of the Sparta. Occurrence of color in the two aquifer systems is shown in figure 13. 


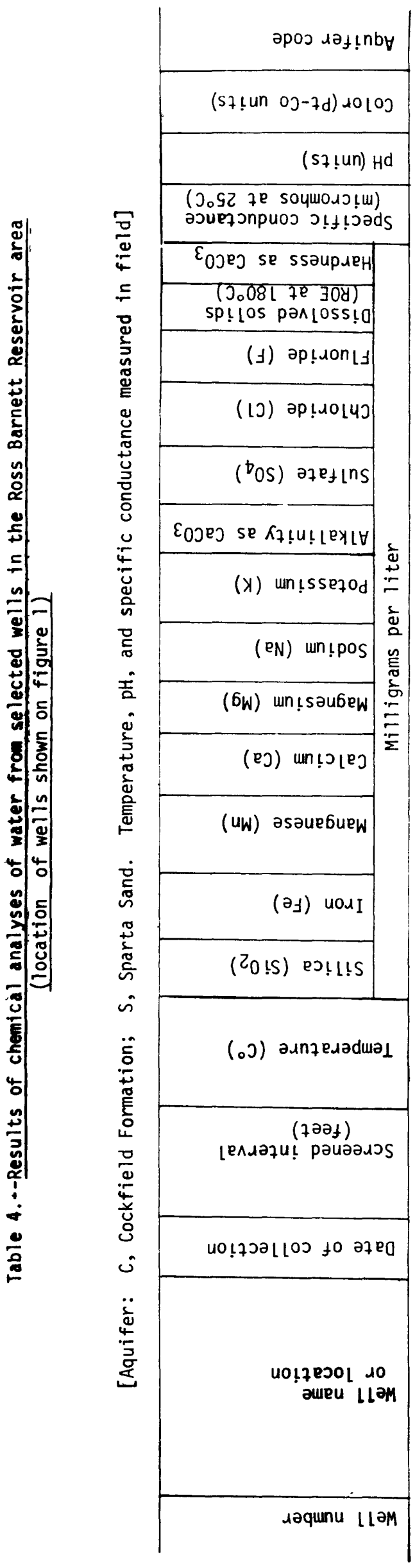

৩৩৩৩৩৩

טưnnưnuvưunnnu

nos

음ำ

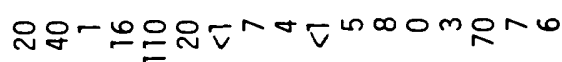

a으

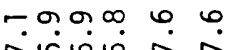

Ln

00

는융유

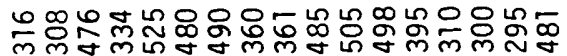

in

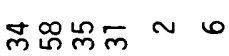

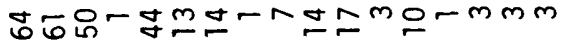

$\stackrel{m}{m}$

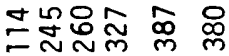

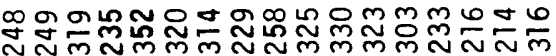

포

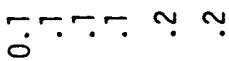

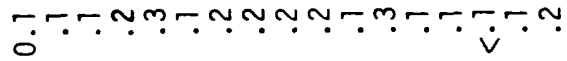

NNo

$\dot{\square} \dot{\infty} \sim \stackrel{\sim}{\sim} \stackrel{m}{m}$

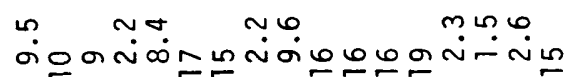

nim

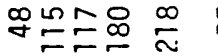

m̄

$\cong \stackrel{\sim}{\sim}$

mogt $\infty$

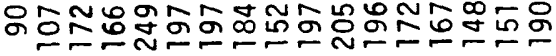

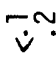

$\sim \sim \sim m \sim \sim$

mก

мंмं $\ddot{\sim} \dot{\sim} \ddot{\sim} \dot{\sim} \dot{\sim} \ddot{\sim} \ddot{-}$

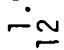

o)

ஸன்ட요 유

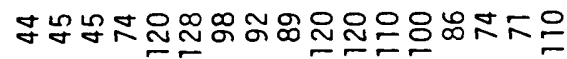

N๐

ก.

- $\dot{\sim} \sim \dot{m}$.

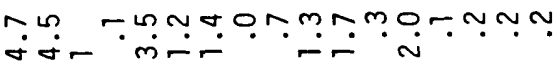

$\ddot{-\infty}$

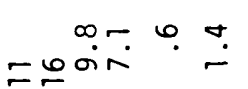

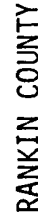

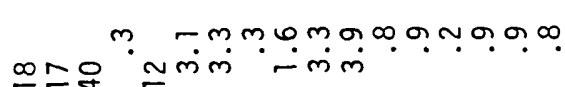

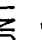

मig

ㅇํㅁำ

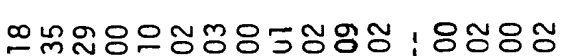

응

앙유으 뜸.

बin

남융요

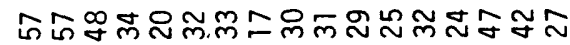

$\dot{\vartheta} \hat{m}$

noOo in n

윰ํㄴ

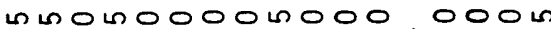
i̊

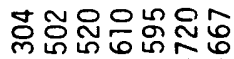

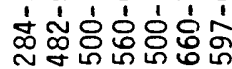

유,

g음

on

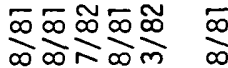

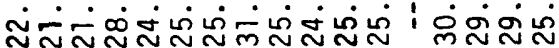

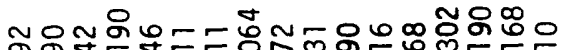

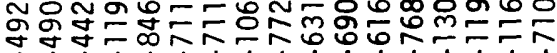

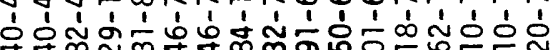

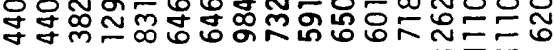

용요

m

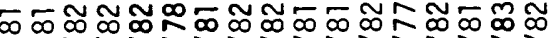

๓๐్

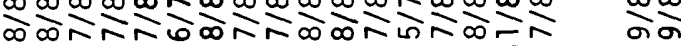

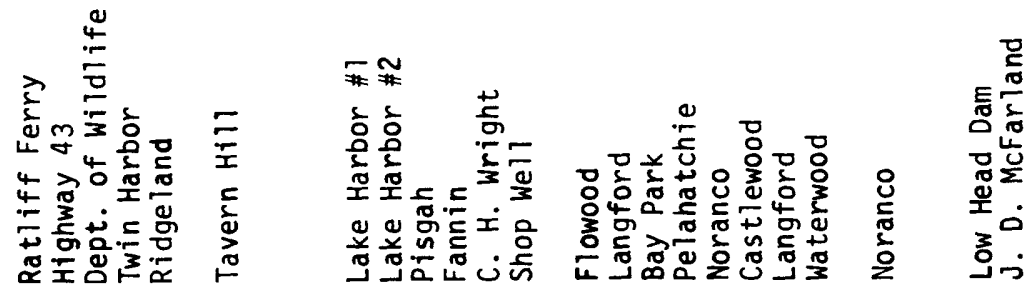

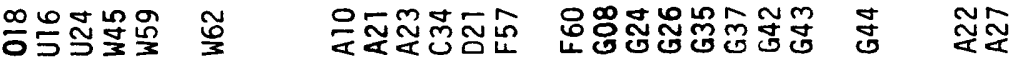




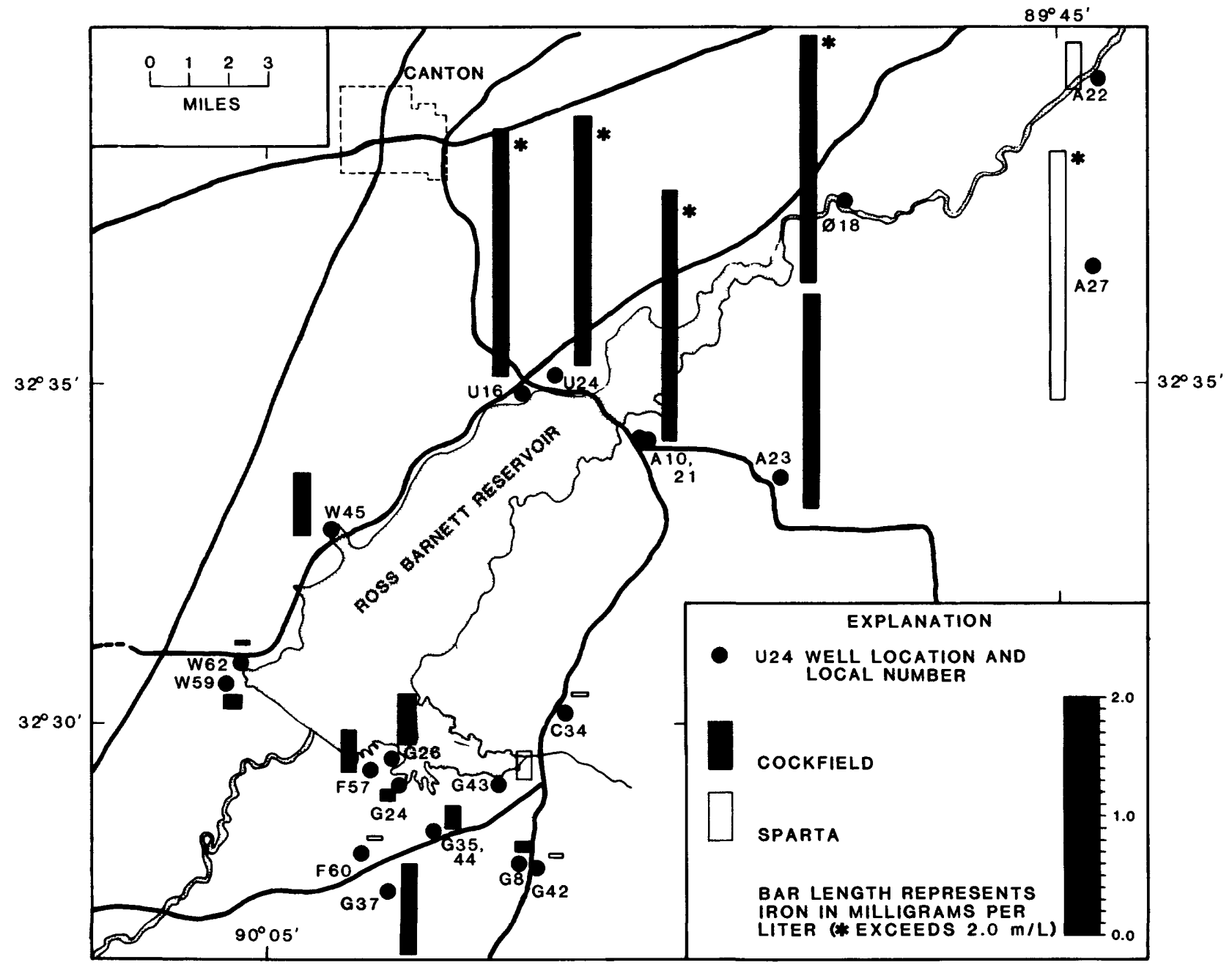

Figure 12.-- Concentration of iron in ground water in the Ross Barnett Reservoir area. 


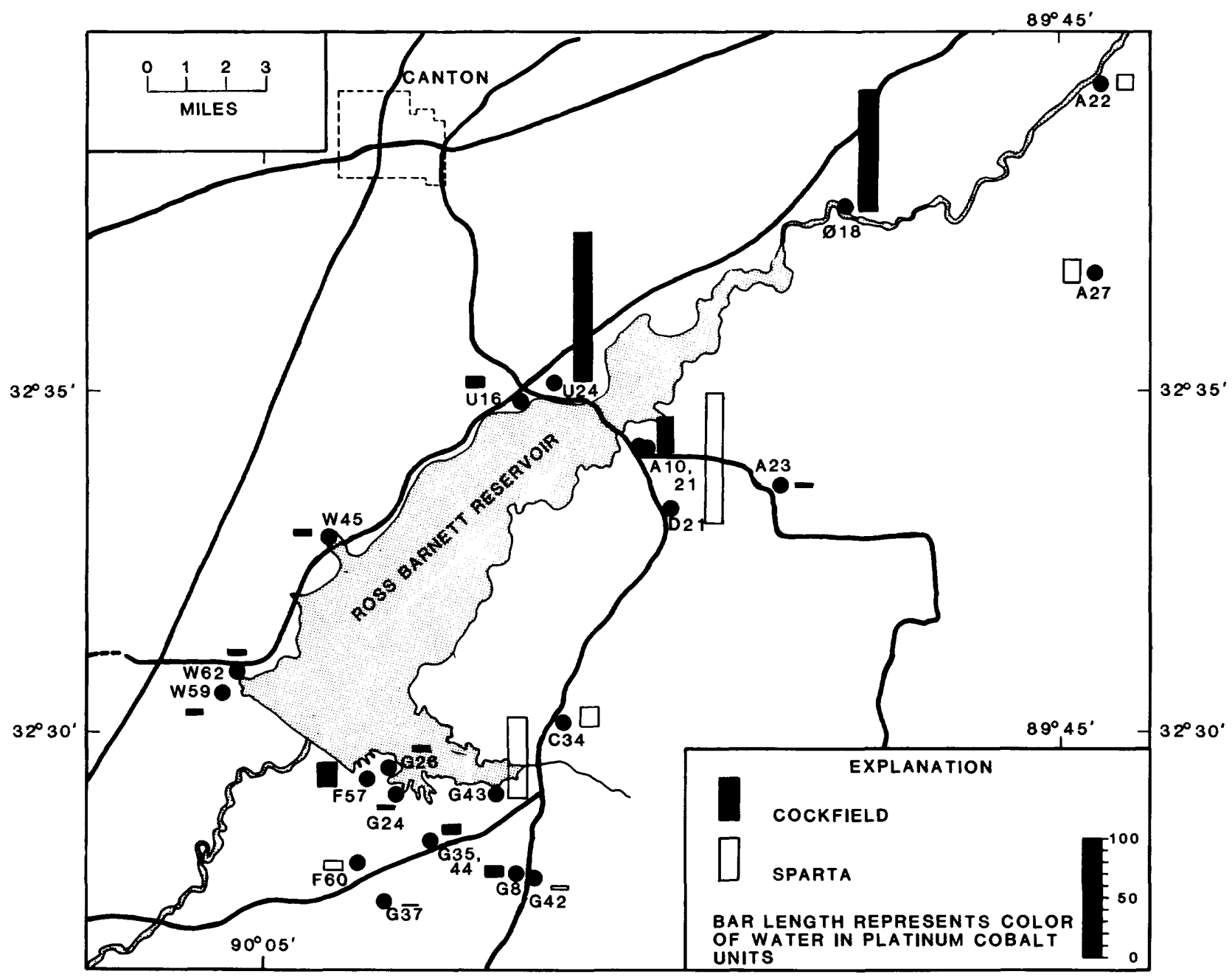

Figure 13.-- Variations in color in ground water in the Ross Barnett Reservoir area. 
Water quality and water levels in the Cockfield aquifer may be influenced by the Jackson dome, where the strata are arched upward several hundred feet. The Cockfield Formation is exposed at the surfac or subcrops beneath the Pearl River alluvium. According to Wasson (1981), "In the small outcrop area of the Cockfield over the Jackson Dome at Jackson there is good recharge potential from precipitation and from the Pearl River." The potentiometric surface in the Cockfield aquifer in the area shows a pronounced recharge effect (Wasson, 1981). The potentiometric surface in the Sparta aquifer (Wasson, 1980c) does not show a recharge effect that might be attributed to leakage from the overlying Cockfield through the confining Cook Mountain Formation; however, the chemical quality of water in the Sparta in the area may be affected by such leakage. The potentiometric surface in the Cockfield is as much as 160 feet higher than the potentiometric surface in the Sparta in the area where the Cockfield outcrops at Jackson (Wasson, 1980c, 1981).

The chemical quality of water in the Cockfield and Sparta Sand aquifers along hydrologic section $B-B^{\prime}$ (see geohydrologic section $B-B^{\prime}$ in figure 7) are shown in figure 14. Modified Stiff (1951) diagrams are used to represent major chemical constituents, in milliequivalents per liter (meq/L), for selected chemical analyses given on table 4 . The example diagram shown in the explanation for hydrologic section $B-B^{\prime}$ depicts a sodium bicarbonate type water with total cations comprised of $4.0 \mathrm{meq} / \mathrm{L}$ sodium plus potassium, $1.0 \mathrm{meq} / \mathrm{L}$ calcium, and $0.5 \mathrm{meq} / \mathrm{L}$ magnesium, and total anions comprised of $4.0 \mathrm{meq} / \mathrm{L}$ al kalinity as $\mathrm{CaCO}_{3}$ (calcium carbonate), $1.0 \mathrm{meq} / \mathrm{L}$ sulfate and $0.5 \mathrm{meq} / \mathrm{L}$ chloride. The diagrams, by representing the chemical quality at the depths at which wells are screened along geohydrologic section $B-B^{\prime}$, show the chemical quality and the changes that were observed in the water moving downgradient in the aquifers from near recharge areas to near the Jackson dome.

The comparatively small size of the diagrams for well 018 in the Cockfield aquifer and well A22 in the Sparta aquifer indicates the low dissolved-mineral content of the water in both aquifers near the recharge areas.

In the Cockfield aquifer the chemical quality exhibits a marked change downgradient from well 018 as indicated by the patterns of the diagrams positioned above the line along section $B-B^{\prime}$. The dissolved-solids concentrations ranged from 245 to $387 \mathrm{mg} / \mathrm{L}$ and are characterized by sulfate concentrations that range from 26 to $60 \mathrm{mg} / \mathrm{L}$. The hardness of water in the four wells in the Cockfield aquifer downgradient of well 018 ranged from 35 to $150 \mathrm{mg} / \mathrm{L}$ as the result of an increase in the calcium and magnesium which are the usual hardness-producing components of water. Further downgradient, the water in the five wells nearest the Jackson Dome are distinct sodium bicarbonate types and hardness values range from 2 to $31 \mathrm{mg} / \mathrm{L}$. 


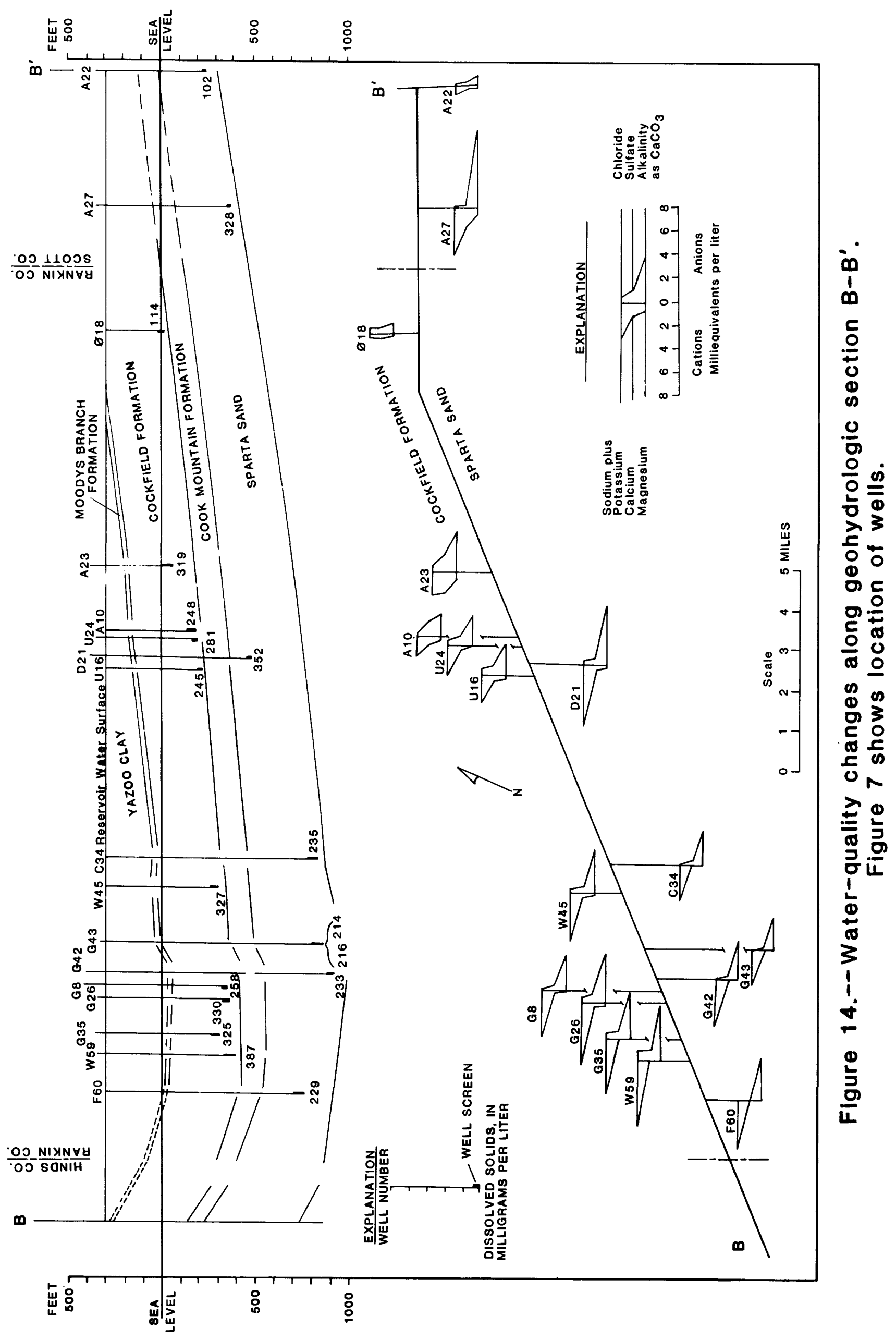


In the Sparta aquifer at well A27 downgradient of well A22, the water is a sodium bicarbonate type, the dissolved-solids concentration is $328 \mathrm{mg} / \mathrm{L}$, and the hardness is $120 \mathrm{mg} / \mathrm{L}$. The mean sulfate concentration in contrast to that in the Cockfield is $9.6 \mathrm{mg} / \mathrm{L}$. The water in the four wells nearest the Jackson dome is a sodium bicarbonate type similar to the water in well A27; however, the dissolved solids and hardness are significantly lower. The anomously high dissolved-solids concentration in wells A27 and D21 may be the result of leakage through openings in the well casing or by the downward movement of water through the annular space outside the well casing. The most likely source of the water is the Cook Mountain Formation. The mean concentration of dissolved solids and hardness of water in these wells are $230 \mathrm{mg} / \mathrm{L}$ and $1 \mathrm{mg} / \mathrm{L}$, respectively.

Apparently, a decrease in hardness and corresponding increase in sodium concentrations in the water at greater depths in the Cockfield and Sparta is not the result of interactions with recharge water from the Pearl River or from precipitation on the exposed outcrops at the Jackson dome. The observed chemical-quality change is consistent with natural cation exchange reactions that occur in water in aquifers during movement through clays that possess the water-softening property. However, a chemical-quality change, unlike that in the cockfield aquifer, is observed in the Sparta aquifer in wells near the Jackson dome. The dissolved solids, iron, and color of water from these wells are significantly lower than in wells D21 and A27 located northeast of the dome. This suggests the high potentiometric head of the Cockfield at the dome induces sufficient leakage into the Sparta Sand to effect a change in the chemical quality. The effect of the apparent recharge is reflected a greater distance from the dome in the Sparta Sand than in the Cockfield. Additional study of the hydrology of the alluvium and the strata that subcrops and outcrops above the dome is needed to assess or postulate the effects of recharge into aquifers that transect the dome.

In 1980, a test well (Rankin G43) was drilled and a water-supply well was constructed in the lower part of the Sparta aquifer (fig. 7). Excessive color concentration in water produced from the well made it undesirable for use in the existing system. After examining the geophysical logs and well screen setting, a television survey was conducted. Reservoir and State officials determined that the well screen extended about 10 feet below the sand into clay that probably was the source of the color in the water being sampled. The lower 20 feet of the 80-foot screen was sealed by the well contractor and the color was reduced from 70 units to 7 units.

The excessive concentration of color in well A22, also screened near the base of the Sparta, indicates that colored water may be more prevalent in the basal strata.

Descriptions of chemical analyses of water from wells in and near the study area are given in table 4 . Locations of sampling sites are shown in figure 2 . 


\section{POTENTIAL FOR FUTURE GROUND-WATER SUPPLY DEVELOPMENT}

The ground-water resource in the Ross Barnett Reservoir area can sustain significant additional development. Specific aquifer test data are not available for well sites located in the study area; however, average values for aquifer hydraulic conductivity and transmissivity may reasonably be assumed to be eqivalent to average values derived from aquifer tests for the nearby Jackson metropolitan area. This conservative assumption can be made because the aquifers in the study area are generally thicker than is average for the Jackson area. The following values are averages for the Jackson area determined by Spiers and Dals in (1979, p. 54, 62, and 65).

\begin{tabular}{lcccc} 
Aquifer & Transmissivity $(T)$ & & $\begin{array}{c}\text { Hydraulic } \\
\text { Conductivity }(K)\end{array}$ & $\begin{array}{c}\text { Specific } \\
\text { Capacity }\end{array}$ \\
\cline { 2 - 4 } & $\begin{array}{l}\text { Meridian-upper } \\
\text { Wilcox }\end{array}$ & $1,200-5,300$ & -- & $2.8-20$ \\
Sparta aquifer & $1,300-2,400$ & 60 & $8-26$ \\
Cockfield aquifer & $1,300-7,300$ & 44 & $4-16$
\end{tabular}

The above data, based on 20 aquifer tests using wells made in the Sparta aquifer and 12 wells made in the Cockfield aquifer, are indicative of the wide range in hydraulic characteristics that may be expected in the irregular sand beds that form the aquifers. The data also indicate, however, that wells capable of producing $500 \mathrm{gal} / \mathrm{min}$ with less than 100 feet of pumping drawdown could reasonably be planned in one of the aquifers at nearly any site. Drawdown availability will be restricted in the Cockfield aquifer in the northeastern part of the study area where wells will be less than 400 feet deep.

Well spacing at present in the area is such that pumping interference between wells is not a significant factor. However, if future planning involves two or more closely spaced wells in the same area in the same aquifer, interference will increase pumping lifts according to the distance between wells.

The availability of cool water (about $68^{\circ} \mathrm{F}$ or less at 300 feet) offers a favorable situation for ground-water heat pumps. If warmer water is needed for heat-exchange purposes, water having a temperature near $90^{\circ} \mathrm{F}$ is also available at reasonable depths in the southwestern part of the area. 


\section{SUMMARY AND CONCLUSIONS}

Substantial reserves of ground water are available for development in the Ross Barnett Reservoir study area. The deepest part of the freshwater section is about 1,600 feet below sea level in the Meridian-upper Wilcox aquifer in the southwest part of the area. Two or more freshwater aquifers are available for water-supply development anywhere in the area, and there are four aquifers available for development in the extreme northeast.

In 1983 about 0.57 million gallons per day were obtained from ground-water sources. Virtually all ground water in the area is used for public supplies.

The Sparta aquifer is the most intensively developed source of ground water in the study area and yields of as much as $1,000 \mathrm{gal} / \mathrm{min}$ or $1.4 \mathrm{Mgal} / \mathrm{d}$ could be obtained from individual wells. The Cockfield, the second highest producing aquifer in the area, can yield up to $1 \mathrm{Mgal} / \mathrm{d}$ to wells. The Meridian-upper Wilcox aquifer is also a potential source of ground water. The chemical quality of water from the Meridian-upper Wilcox is good as far downdip as the aquifer contains freshwater although the dissolved-solids concentration is above $500 \mathrm{mg} / \mathrm{L}$ in the southwest.

Water-level declines in the study area have not been excessive since 1965 and the area is mostly updip and outs ide the deeper parts of the cones of depression that are centered around Jackson (see Wasson, 1980c and 1981). Pumping levels are not excessive and drawdown space in wells, particulary in those in the Sparta aquifer, is sufficient to accomodate several hundred feet of additional water-level decline.

There are problems with water quality in some places in the Sparta and Cockfield aquifers. Excessive color of water is a local problem in both the Sparta and Cockfield aquifers. Higher iron concentrations that occur at places in the Cockfield aquifer are generally near the outcrop area. High color concentrations in the Sparta aquifer may be more prevalent in the basal strata.

The selection of an aquifer at any site for a water supply in the Ross Barnett Reservoir area may be contingent on the quality of water in the aquifers at the site. Because the iron concentration and color are not predictable, it is advisable to obtain water samples from the potential source before the selection is made. 


\section{SELECTED REFERENCES}

Baughman, Wilbur T., McCutcheon, Thomas E., Bicker, Alvin R., Jr., Dinkins, Theo H., Jr., and Shows, Thad N., 1971, Rankin County geology and mineral resources: Mississippi Geological Survey Bulletin 115, 226 p.

Bicker, A. R., Jr., 1969, Geologic map of Mississippi: Mississippi Geological Survey.

Boswel1, E. H., 1976a, The lower Wilcox aquifer in Mississippi: U.S. Geological Survey Water-Resources Investigations Map 60-75.

1976b, The Meridian-upper Wilcox aquifer in Mississippi: U.S. Geological Survey Water-Resources Investigations Map 76-79.

Harvey, E. J., Callahan, J. A., and Wasson, B. E., 1961, Ground-water resources of Hinds, Madison, and Rankin Counties, Mississippi, pt. II, basic data: Mississippi Board of Water Commissioners Bulletin 61-2, $146 \mathrm{p}$.

1964, Ground-water resources of Hinds, Madison, and Rankin Counties, Mississippi: Mississippi Board of Water Commissioners Bulletin 64-1, 38 p.

Moore, William H., Bicker, Alvin R., McCutcheon, Thomas E., and Parks, William S., 1965, Hinds County geology and mineral resources: Mississippi Geological Survey Bulletin 105, 244 p.

Newcome, Roy, Jr., 1976, The Sparta aquifer system in Mississippi: U.S. Geological Survey Water-Resources Investigations Map 76-7.

Priddy, R. R., 1960, Madison County geology: Mississippi State Geological Survey Bulletin 88, $129 \mathrm{p}$.

Spiers, C. A., 1977a, The Cockfield aquifer in Mississippi: U.S. Geological Survey Water-Resources Investigations 77-17, map.

1977b, The Winona-Tallahatta aquifer in Mississippi: U.S. Geological Survey Water-Resources Investigations 77-125, map.

Spiers, C. A., and Dalsin, G. J., 1979, Water for municipal and industrial development in Hinds, Madison, and Rankin Counties, Mississippi: Mississippi Research and Development Bulletin, 78 p.

Stiff, H. A., Jr., 1951, Technical note 84-The interpretation of chemical analysis by means of patterns: Journal of Petroleum Technology, vol. 3, No-10, p. 15-16.

U.S. Environmental Protection Agency, 1976, National interim primary drinking water regulations: EPA-570/9-76-003, 159 p. 
Wasson, B. E., 1980a, Potentiometric map of the lower Wilcox aquifer in Mississippi, Fall 1979: U.S. Geological Survey Water-Resources Investigations Map 80-597, 1 sheet.

1980b, Potentiometric map of the Meridian-upper Wilcox aquifer in Mississippi, Fall 1979: U.S. Geological Survey Water-Resources Investigations Map 80-590, 1 sheet.

1980c, Potentiometric map of the Sparta aquifer system in Mississippi, Fall 1980: U.S. Geological Survey Water-Resources Investigation Map 81-1051, 1 sheet.

1981, Potentiometric map of the Cockfield aquifer in Mississippi, Fall 1980: U.S. Geological Survey Water-Resources Investigation Map 81-1053, 1 sheet. 